\title{
No genetic relationship between TLR2 rs4696480, rs3804I00, and rs3804099 gene polymorphisms and female breast cancer in Saudi populations
}

This article was published in the following Dove Press journal:

OncoTargets and Therapy

27 April 2017

Number of times this article has been viewed

\author{
Abdelhabib Semlali' \\ Mikhlid Almutairi ${ }^{2}$ \\ Narasimha Reddy Parine' \\ Abdullah Al Amri' \\ Jilani P Shaik' \\ Abdulrahman Al Naeem ${ }^{3}$ \\ Sana Abdulla Ajaj ${ }^{4}$ \\ Mahmoud Rouabhia ${ }^{5}$ \\ Mohammad Saud Alanazi \\ 'Department of Biochemistry, \\ ${ }^{2}$ Zoology Department, College \\ of Science, King Saud University, \\ ${ }^{3}$ Department of Women's Imaging, \\ King Fahad Medical City, ${ }^{4}$ Family \\ Medicine Department, College \\ of Medicine, King Saud University, \\ Riyadh, Kingdom of Saudi Arabia; \\ ${ }^{5}$ Groupe de Recherche en \\ Écologie Buccale, Département \\ de Stomatologie, Faculté de \\ Médecine Dentaire, Université \\ Laval, Québec, QC, Canada
}

Abstract: Breast cancer (BC) is the most common cause of cancer-related deaths among women in the Kingdom of Saudi Arabia. An association between the dysregulation of innate immunity, primarily the deregulation of Toll-like receptors (TLRs), and BC development was described a long time ago. Several studies have reported that $\mathrm{BC}$ risk factors appear to be related to the interaction between certain genes and exposure to various environmental factors. Here, we investigated the potential correlation of three TLR2 single-nucleotide polymorphisms (SNPs; rs3804100, rs4696480, and rs3804099) with the development of BC in female patients from Saudi Arabia. We collected 126 blood samples from women with BC and 146 blood samples from healthy women without any clinical signs of BC. The genotypic frequencies of TLR2 polymorphisms were assayed. Our results showed that the genotypic and allelic frequencies of TLR2 did not differ significantly between BC patients and healthy controls. However, the distributions of rs $3804100(1350 \mathrm{~T} / \mathrm{C})$ genotypes in $\mathrm{BC}$ groups were $1 \%, 19 \%$, and $80 \%$ for $\mathrm{CC}$, $\mathrm{CT}$, and TT, respectively. In the control group, the $r s 3804100(1350 \mathrm{~T} / \mathrm{C})$ genotype distributions were $3 \%, 18 \%$, and $79 \%$ for CC, CT, and TT, respectively. The SNP rs3804100 homozygous "TT" genotype was not associated with the risk of developing $\mathrm{BC}$ in the $\mathrm{BC}$ patients compared with controls (odds ratio [OR], 4.5; confidence interval [CI], 0.49-41.02; $P=0.145$ ). The TLR2 rs4696480 AA genotype was observed in $23 \%$ of $\mathrm{BC}$ patients compared to $18 \%$ of control individuals, the AT genotype was seen in $40 \%$ of BC patients and $46 \%$ of control individuals, and the TT genotype was observed in $37 \%$ of $\mathrm{BC}$ patients and $36 \%$ of normal controls. Our results did not show any difference in genotypic frequency between $\mathrm{BC}$ patients and normal controls for the TLR2 rs3804099 SNP; however, the (C) phenotypic frequency was 49\% in BC patients and 53\% in controls. The ( $\mathrm{T}$ ) phenotypic frequency was $51 \%$ and $47 \%$ in $\mathrm{BC}$ patients and normal patients, respectively. These findings indicate that there is no association between the TLR2 polymorphisms tested and BC susceptibility in the female population from the Kingdom of Saudi Arabia. We suggest using other TLR2 SNPs to investigate the possible relationship between innate immunity deregulation by disruption of TLR2 and potential BC development. Keywords: breast cancer, genotyping, polymorphism, Toll-like receptors

\section{Background}

Breast cancer $(\mathrm{BC})$ is one of the most prevalent forms of cancer in women worldwide and the most frequent cause of cancer-related deaths among women in the Kingdom of Saudi Arabia. In 2012, BC accounted for $25.8 \%$ of all newly diagnosed cancers in the female Saudi population (http://www.scr.org.sa). The median age of women diagnosed with BC is $\sim 63$ years in the US and Western Europe, compared with 47 years in the Kingdom of Saudi Arabia. ${ }^{2}$ Hence, BC is an important public health problem in 
Saudi Arabian populations. Studies have shown that chronic inflammation can be associated with the cellular mechanisms involved in cancer progression, such as the role of Tolllike receptors (TLRs) and their signaling pathways. ${ }^{3,4}$ TLR family members are involved in the maintenance of innate immunity in mature human cells ${ }^{5}$ and play an important role in the early defense against invading microorganisms and parasites. ${ }^{6}$ To date, more than ten different types of TLRs have been identified in human beings (TLR1-TLR10) and are classified into two categories according to their cellular localization. The first group, consisting of TLR1, TLR2, TLR4, TLR5, and TLR6, is localized on the surface of the cell. The second group, which includes TLR3, TLR7, TLR8, and TLR9, is localized on the endoplasmic reticulum, lysosomes, or endosomes. The expression of TLRs has recently been described in different cancer types; however, the role of TLRs in cancer development remains unclear.,7 TLRs can be used as therapeutic targets in immune disorders and different types of cancer, because they can induce either apoptosis or anti-cancer responses. ${ }^{8}$ Studies have demonstrated that reduction in TLR4 expression leads to increased colorectal cancer metastasis..$^{9,10}$ Several studies indicate that polymorphisms and mutations of TLRs are associated with immune system deregulation and cancer development. For example, novel gene mutations in two TLRs (TLR1 and TLR2) are correlated with increased susceptibility to infection by Mycobacterium avium subsp. Paratuberculosis. ${ }^{11}$ Polymorphisms in TLR genes may shift the balance between pro- and anti-inflammatory cytokines, modulating the risk of infection, chronic inflammation, and cancer. ${ }^{12}$ In addition, basic and epidemiological studies have investigated the association between TLR polymorphism and almost all cancer types, particularly those caused by carcinogenic infectious agents, such as gastric cancer, colorectal cancer, liver cancer, cervical cancer, and nasopharyngeal carcinoma. ${ }^{13}$ Semlali et $\mathrm{al}^{14}$ have reported clear evidence of an association between a TLR4 polymorphism and susceptibility to colon cancer in the Saudi population. Single-nucleotide polymorphisms (SNPs) of the TLR1, TLR6, and TLR10 genes are associated with increased prostate cancer risk, ${ }^{15}$ while SNPs of the TLR2 and TLR4 genes are associated with gastric cancer development. ${ }^{16,17}$ In addition, polymorphisms in either TLR2 or TLR4 (Asp299Gly) are correlated with prostate cancer development in north Indian patients. ${ }^{18,19}$ Slattery et $\mathrm{al}^{20}$ have linked a TLR4 SNP (rs11536898) with colon cancer. A previous study by Kim et $\mathrm{al}^{21}$ has shown that TLR2 SNPs (rs3804099 and rs3804100) are significantly associated with papillary thyroid cancer (PTC) in Korean populations.
Wang et al have described an association between four polymorphisms of the TLR2 gene (rs5743708, -196 to -174 del polymorphism, rs3804099, and rs3804100) and cancer risk. Polymorphisms -196 to -174 del and rs3804099 were associated with increased and decreased risks of cancer, respectively. ${ }^{22}$ Recently, we have shown that the TLR2 SNP rs3804099 is associated with colon cancer in female patients aged $<57$ years.

The TLR2 rs4696480 and rs3804100 SNPs have been identified in different types of malignances, but not in BC. The TLR2 rs3804099 SNP has been reported in BC, but not in Saudi Arabian populations. Therefore, we wanted to examine the potential correlation of TLR2 SNPs rs3804100, rs4696480, and rs3804099 with the development of BC in female Saudi patients.

\section{Patients and methods}

\section{Patient characteristics}

This population-based case-control study was carried out in the Kingdom of Saudi Arabia. The BC samples comprised blood samples isolated from 126 Saudi women with BC. The control samples comprised 146 blood samples from healthy women without any clinical signs of BC. All samples were obtained from sex- and age-matched (within 5 years) individuals of King Faisal Medical City of Riyadh prior to any medical treatment. The median age was $48 \pm 8.2$ years, with $64.6 \%$ and $46.6 \%$ of women being postmenopausal in the $\mathrm{BC}$ and control groups, respectively. The eligibility criteria for controls included demonstrating normal mammography results and no previous history of cancer. Written informed consent was obtained from all participants, and approval was received from the ethics review committee of King Faisal Medical City (local ethics committee number 15-089E). All participants completed a self-administered questionnaire on demographic characteristics (eg, age, sex, etc.), medical conditions, familial history of cancer, and reproductive histories. Furthermore, immunohistochemistry was performed on estrogen receptor (ER). The clinical and pathological characteristics are listed in Table 1. Genomic DNA was isolated from blood samples of control and case groups.

\section{Extraction of genomic DNA}

Blood samples $(3 \mathrm{~mL})$ of the participants were collected in vacutainers containing 5\% ethylenediaminetetraacetic acid (EDTA). Genomic DNA was isolated from whole blood samples using a QIAamp DNA Blood Mini Kit (Qiagen, Valencia, CA, USA), according to the manufacturer's protocol. DNA concentration was determined 
Table I Clinical characteristics of Saudi BC cases and healthy controls used for genotyping

\begin{tabular}{llll}
\hline Variable & Character & Patients, $\mathbf{n}$ & Controls, $\mathbf{n}$ \\
\hline Total people & na & 126 & 146 \\
Age (years), & $\leq 48$ years & 44 & 57 \\
median age (48 \pm 8.2$)$ & $>48$ years & 82 & 55 \\
ER & ER+ & 75 & na \\
& ER- & 49 & na \\
PR & PR+ & 71 & na \\
& PR- & 55 & na \\
HER status & HER+ & 49 & na \\
& HER- & 78 & na \\
\hline
\end{tabular}

Abbreviations: $B C$, breast cancer; ER, estrogen receptor; PR, progesterone receptor; HER, human epidermal growth factor receptor; na, not applicable.

using a NanoDrop 8000 spectrophotometer (Thermo Fisher Scientific, Waltham, MA, USA), and DNA purity was tested by calculating the A260/A280 and A260/A230 ratios.

\section{Genotyping assay}

The TLR2 rs4696480, rs3804100, and rs3804099 SNPs were genotyped using a TaqMan allelic discrimination assay, as described previously, ${ }^{14,23}$ with an ABI 7500 Real-Time PCR Instrument (Applied Biosystems, Foster City, CA, USA). The SNP positions are described in Table S1. DNA (10-20 ng) from each sample was added to $5.6 \mu \mathrm{L}$ of $2 \times$ TaqMan Universal Master Mix and $200 \mathrm{nM}$ primers in an overall reaction volume of $10 \mu \mathrm{L}$. Primer and probe mixtures were purchased from the assays-on-demand service of Applied Biosystems. A total of $5 \%$ of the samples were randomly selected for repeat analysis as a quality control measure to verify genotyping quality.

\section{Statistical analysis}

Genotypic and allelic frequencies were computed and checked for deviation from the Hardy-Weinberg equilibrium (HWE; http://ihg2.helmholtz-muenchen.de/cgi-bin/hw/ hwa1.pl). Case and control group comparisons and other genetic comparisons were performed using the chi-square test and allelic odds ratios (ORs). The 95\% confidence intervals (CIs) were calculated by Fisher's exact test (two tailed). Statistical analysis was conducted using the Statistical Package for the Social Sciences (SPSS) 16.0 software for Windows. $P$-values $<0.05$ were considered as statistically significant.

\section{Results}

\section{Analysis of clinical data parameters}

The current study included $126 \mathrm{BC}$ cases and 146 healthy controls. The clinical characteristics of the patients in both groups were compared. These characteristics included patient age, nationality, family history, smoking habits, BC stage, medications, ER status, and presence of other diseases. The study population was classified into two age groups: $>48$ years and $<48$ years. The mean age of the $\mathrm{BC}$ patients and healthy controls $(48 \pm 8.2)$ was not statistically different (Table 1).

\section{Interactions between TLR2 polymorphisms and $B C$ risk in} Saudi Arabian patients

Three TLR2 SNPs (rs4696480 A/T, rs3804099 C/T, and rs3804100 C/T) were genotyped and assessed for deviation from the HWE. The phenotypic and genotypic characteristics of the Saudi Arabian patient and control groups are summarized in Table 2. The TLR2 genotypic distribution is presented in Table 3. The genotype and allele frequencies of TLR2 did not differ significantly between BC patients and controls. However, the distributions of rs 3804100 $(1,350 \mathrm{~T} / \mathrm{C})$ genotypes in $\mathrm{BC}$ groups were $1 \%, 19 \%$, and $80 \%$ for CC, CT, and TT, respectively, whereas in control groups, the distributions were 4 (0.03), 27 (0.18), and 115 (0.79) for CC, CT, and TT, respectively. The homozygous rs3804100 "TT" SNP genotype did not show any association with $\mathrm{BC}$ patients compared with normal controls (OR, 4.5; CI, 0.49-41.02; $P=0.145$; Table 3). For TLR2 rs4696480, the AA genotype was present in $23 \%$ of BC patients and $18 \%$ of control subjects, AT was present in $40 \%$ of BC patients and $46 \%$ of control patients, and TT was present in $37 \%$ of $\mathrm{BC}$ patients and $36 \%$ of control patients. Our results for the TLR2 rs3804099 SNP did not show any difference in genotype frequency between $\mathrm{BC}$ patients and normal controls.

Table 2 Distribution of genotypes and allele frequencies of the TLR2 gene loci among Saudi BC patients and healthy controls

\begin{tabular}{lllll}
\hline Genotype & Cases, n & HWE $P$-value & Controls, n & HWE P-value \\
\hline rs3804I00 & & & & \\
CC & I & 0.728395 & 4 & 0.051917 \\
CT & 24 & & 27 & \\
TT & 99 & & 115 & \\
rs4696480 & & & & \\
AA & 29 & 0.306821 & 25 & 0.048883 \\
AT & $5 \mathrm{I}$ & & 63 & \\
TT & 46 & & 50 & \\
rs3804099 & & & & \\
CC & 32 & 0.480478 & 42 & 0.424288 \\
CT & 58 & & 71 & \\
TT & 35 & & 33 & \\
\hline
\end{tabular}

Abbreviations: TLR2, Toll-like receptor 2; BC, breast cancer; HWE, HardyWeinberg equilibrium. 
Table 3 Genotype frequencies of TLR2 gene polymorphism in Saudi BC patients and healthy controls

\begin{tabular}{|c|c|c|c|c|c|c|c|c|}
\hline Gene & SNP ID & Genotype & Breast, n (\%) & Controls, n (\%) & OR & $95 \% \mathrm{Cl}$ & $\chi^{2}$-value & $P$-value \\
\hline \multirow[t]{21}{*}{ TLR2 } & rs3804I00 & & $n=124$ & $n=146$ & & & & \\
\hline & & $\mathrm{CC}$ & $\mathrm{I}(0.0 \mathrm{I})$ & $4(0.03)$ & Ref & & & \\
\hline & & $\mathrm{CT}$ & $24(0.19)$ & $27(0.18)$ & 4.800 & $0.496-46.472$ & 2.14 & 0.14312 \\
\hline & & TT & $99(0.80)$ & II 5 (0.79) & 4.500 & $0.494-41.022$ & 2.12 & 0.14563 \\
\hline & & $\mathrm{CT}+\mathrm{TT}$ & $123(0.99)$ & $142(0.97)$ & 4.556 & $0.502-41.382$ & 2.17 & 0.14078 \\
\hline & & C & $26(0.10)$ & $35(0.12)$ & Ref & & & \\
\hline & & $\mathrm{T}$ & $222(0.90)$ & $257(0.88)$ & 1.220 & $0.692-2.151$ & 0.47 & 0.49199 \\
\hline & rs4696480 & & $n=126$ & $n=138$ & OR & $95 \% \mathrm{Cl}$ & $\chi^{2}$-value & $P$-value \\
\hline & & AA & $29(0.23)$ & $25(0.18)$ & Ref & & & \\
\hline & & AT & $51(0.40)$ & $63(0.46)$ & 0.769 & $0.387-1.528$ & 0.56 & 0.45350 \\
\hline & & TT & $46(0.37)$ & $50(0.36)$ & 0.812 & $0.403-1.639$ & 0.34 & 0.56167 \\
\hline & & $\mathrm{AT}+\mathrm{TT}$ & $97(0.77)$ & $1 \mathrm{I} 3(0.82)$ & 0.789 & $0.420-1.483$ & 0.54 & 0.46168 \\
\hline & & A & $109(0.43)$ & II $3(0.4 \mathrm{I})$ & Ref & & & \\
\hline & & $\mathrm{T}$ & I $43(0.57)$ & I 63 (0.59) & 0.908 & $0.630-1.310$ & 0.26 & 0.60681 \\
\hline & rs3804099 & & $n=125$ & $n=I 46$ & OR & $95 \% \mathrm{Cl}$ & $\chi^{2}$-value & $P$-value \\
\hline & & $\mathrm{CC}$ & $32(0.26)$ & $42(0.29)$ & Ref & & & \\
\hline & & $\mathrm{CT}$ & $58(0.46)$ & 7I (0.48) & 1.185 & $0.643-2.183$ & 0.30 & 0.58569 \\
\hline & & TT & $35(0.28)$ & $33(0.22)$ & 1.430 & $0.7|0-2.88|$ & 1.01 & 0.31593 \\
\hline & & $\mathrm{CT}+\mathrm{TT}$ & $93(0.74)$ & $104(0.7 \mathrm{I})$ & 1.267 & $0.717-2.238$ & 0.67 & 0.41469 \\
\hline & & C & $122(0.49)$ & I $55(0.53)$ & Ref & & & \\
\hline & & $\mathrm{T}$ & $128(0.5 \mathrm{I})$ & I $37(0.47)$ & 1.211 & $0.844-1.737$ & 1.08 & 0.2995 I \\
\hline
\end{tabular}

Abbreviations: TLR2, Toll-like receptor 2; BC, breast cancer; SNP, single-nucleotide polymorphism; OR, odds ratio; Cl, confidence interval; Ref, reference.

However, the TLR2 rs3804099 (C) genotype frequency was $49 \%$ and $53 \%$ in BC and control subjects, respectively. The TLR2 rs3804099 (T) genotype frequency was 51\% and 47\% in $\mathrm{BC}$ patients and control patients, respectively (Table 3).

\section{Correlation between genotype distribution of TLR2 gene polymorphisms and clinical parameters}

The genotype frequencies of TLR2 were analyzed based on patient age in this study. This indicated that the median age of $\mathrm{BC}$ onset in the patients examined was 58 years. We further evaluated the relationship between the three TLR2 gene polymorphisms and patients of younger age at BC diagnosis by stratifying the patients as either $\leq 48$ years $(n=44$ for $\mathrm{BC}$ patients and $\mathrm{n}=57$ for control patients) or $>48$ years ( $n=82$ for $B C$ patients and $n=55$ for control patients) of age. The genotype distributions of TLR2 SNPs, along with the statistical analysis, are shown in Tables 4 and 5. None of the three TLR2 SNPs analyzed showed any significant association with $\mathrm{BC}$, irrespective of stratification. For instance, the distributions of rs3804100 (1350 T/C) genotypes in $\mathrm{BC}$ groups were $2 \%, 26 \%$, and $72 \%$ for $\mathrm{CC}, \mathrm{CT}$, and $\mathrm{TT}$, respectively, whereas in control groups, the distributions were $5 \%, 20 \%$, and $75 \%$ for CC, CT, and TT, respectively. The heterozygous "CT" genotype of the rs3804100 SNP was not associated with increased risk of developing $\mathrm{BC}$ in $\mathrm{BC}$ patients compared to matched healthy controls
(OR, 3.00; CI, 0.27-33.48; $P=0.356$; Table 4). As shown in Table 5, the frequency of the rs4696480 (Arg753Gln) genotypes were $23 \%, 40 \%$, and $37 \%$ for $\mathrm{CC}, \mathrm{CT}$, and TT, respectively, in $\mathrm{BC}$ patients and $17 \%, 45 \%$, and $38 \%$ for $\mathrm{CC}$, $\mathrm{CT}$, and TT, respectively, in controls.

We examined the relationship between BC risk and individual SNPs according to ER status of the cancer cells. The TLR2 genotype distributions were compared between patients with estrogen receptor positive $(E R+v e) B C$ cells and estrogen receptor negative (ER - ve) BC cells, with $\mathrm{ER}+\mathrm{ve}$ and $\mathrm{ER}-\mathrm{ve}$ healthy control individuals, respectively (Tables 6 and 7). None of the SNPs examined were associated with $\mathrm{BC}$ in the $\mathrm{ER}+\mathrm{ve}$ group compared to the controls. As shown in Table 6, the frequencies of rs3804099 (Asn199Asn) genotypes in BC patients were 28\%, 48\%, and $24 \%$ for CC, CT, and TT, respectively, whereas in controls, the frequencies were $29 \%, 49 \%$, and $22 \%$ for CC, CT, and TT, respectively (Table 6). Furthermore, no significant difference in the distribution of TLR2 genotypes between the ER -ve $\mathrm{BC}$ cases and the controls was observed, with the exception of the T allele of SNP rs3804099, which showed a significant correlation with $\mathrm{BC}$ patients compared with healthy controls (OR, 1.61; CI, 0.996-2.619; $P=0.005$; Table 7).

\section{Discussion}

Development of cancer is usually associated with a dysfunction of the human immune system; therefore, cancer risk is 
Table 4 Comparison of genotype frequencies of SNPs in the TLR2 gene between Saudi BC cases (patient age $\leq 48$ years) and healthy controls

\begin{tabular}{|c|c|c|c|c|c|c|c|c|}
\hline Gene & SNP ID & Genotype & Breast, n (\%) & Controls, n (\%) & OR & $95 \% \mathrm{Cl}$ & $\chi^{2}$-value & $P$-value \\
\hline \multirow[t]{21}{*}{ TLR2 } & rs3804I00 & & $n=43$ & $n=57$ & & & & \\
\hline & & $\mathrm{CC}$ & I (0.02) & $3(0.05)$ & Ref & & & \\
\hline & & $\mathrm{CT}$ & II (0.26) & II $(0.20)$ & 3.000 & $0.27-33.48$ & 0.85 & 0.35622 \\
\hline & & $\mathrm{TT}$ & $31(0.72)$ & $43(0.75)$ & 2.163 & $0.21-21.78$ & 0.45 & 0.50350 \\
\hline & & $\mathrm{CT}+\mathrm{TT}$ & $42(0.98)$ & $54(0.95)$ & 2.333 & $0.234-23.246$ & 0.55 & 0.45799 \\
\hline & & C & $13(0.15)$ & $17(0.15)$ & Ref & & & \\
\hline & & $\mathrm{T}$ & $73(0.85)$ & $97(0.85)$ & 0.984 & $0.450-2.154$ & 0.00 & 0.96809 \\
\hline & rs4696480 & & $n=44$ & $n=57$ & OR & $95 \% \mathrm{Cl}$ & $\chi^{2}$-value & $P$-value \\
\hline & & AA & $10(0.23)$ & $12(0.21)$ & Ref & & & \\
\hline & & AT & I8 (0.4I) & $24(0.42)$ & 0.900 & $0.319-2.542$ & 0.04 & 0.84231 \\
\hline & & $\mathrm{TT}$ & $16(0.36)$ & $21(0.37)$ & 0.914 & $0.316-2.644$ & 0.03 & 0.86860 \\
\hline & & $\mathrm{AT}+\mathrm{TT}$ & $34(0.77)$ & 45 (0.79) & 0.907 & $0.35 I-2.345$ & 0.04 & 0.83978 \\
\hline & & A & $38(0.43)$ & $48(0.42)$ & Ref & & & \\
\hline & & $\mathrm{T}$ & $50(0.57)$ & $66(0.58)$ & 0.957 & $0.545-1.679$ & 0.02 & 0.87805 \\
\hline & rs3804099 & & $n=44$ & $n=57$ & OR & $95 \% \mathrm{Cl}$ & $\chi^{2}$-value & $P$-value \\
\hline & & $\mathrm{CC}$ & $10(0.23)$ & $16(0.28)$ & Ref & & & \\
\hline & & $\mathrm{CT}$ & $25(0.57)$ & $28(0.49)$ & 1.429 & $0.549-3.718$ & 0.54 & 0.46407 \\
\hline & & $\mathrm{TT}$ & $9(0.20)$ & $13(0.23)$ & 1.108 & $0.347-3.535$ & 0.03 & 0.86283 \\
\hline & & $\mathrm{CT}+\mathrm{TT}$ & $34(0.77)$ & $4 \mathrm{I}(0.72)$ & 1.327 & $0.533-3.30 \mathrm{I}$ & 0.37 & 0.54255 \\
\hline & & $\mathrm{C}$ & $45(0.5 \mathrm{I})$ & $60(0.53)$ & Ref & & & \\
\hline & & $\mathrm{T}$ & $43(0.49)$ & $54(0.47)$ & 1.062 & $0.609-1.853$ & 0.04 & 0.83296 \\
\hline
\end{tabular}

Abbreviations: SNP, single-nucleotide polymorphism; TLR2, Toll-like receptor 2; BC, breast cancer; OR, odds ratio; Cl, confidence interval; Ref, reference.

two to three times greater in patients with immunodeficiency. ${ }^{24}$ It has been shown that colon cancer risk is closely related to the downregulation of TLR2, one of the members of the TLR family involved in innate immunity defense against microorganisms. ${ }^{25,26}$ This downregulation occurs because of the SNPs, epigenetic changes, or microRNA modifications. Previous studies have shown that genetic variations in TLR2, particularly those arising from polymorphisms, are often

Table 5 Comparison of genotype frequencies of SNPs in the TLR2 gene between Saudi BC cases (patient age $>48$ years) and healthy controls

\begin{tabular}{|c|c|c|c|c|c|c|c|c|}
\hline Gene & SNP ID & Genotype & Breast, n (\%) & Controls, n (\%) & OR & $95 \% \mathrm{Cl}$ & $\chi^{2}$-value & $P$-value \\
\hline \multirow[t]{21}{*}{ TLR2 } & rs3804I00 & & $n=8 I$ & $n=55$ & & & & \\
\hline & & $\mathrm{CC}$ & $0(0.00)$ & I (0.02) & Ref & & & \\
\hline & & $\mathrm{CT}$ & $13(0.16)$ & $9(0.16)$ & 4.263 & $0.156-116.34$ & 1.36 & 0.24370 \\
\hline & & TT & $68(0.84)$ & $45(0.82)$ & 4.516 & $0.18-113.32$ & 1.49 & 0.22201 \\
\hline & & $\mathrm{CT}+\mathrm{TT}$ & $81(1)$ & $54(0.98)$ & 4.486 & $0.179-112.162$ & 1.48 & 0.22321 \\
\hline & & $\mathrm{C}$ & $13(0.08)$ & II (0.10) & Ref & & & \\
\hline & & $\mathrm{T}$ & $149(0.92)$ & $99(0.90)$ & 1.274 & $0.549-2.956$ & 0.32 & 0.57296 \\
\hline & rs4696480 & & $n=82$ & $n=53$ & OR & $95 \% \mathrm{Cl}$ & $\chi^{2}$-value & $P$-value \\
\hline & & AA & $19(0.23)$ & $9(0.17)$ & Ref & & & \\
\hline & & AT & $33(0.40)$ & $24(0.45)$ & 0.651 & $0.25 \mathrm{I}-1.687$ & 0.78 & 0.37573 \\
\hline & & $\mathrm{TT}$ & $30(0.37)$ & $20(0.38)$ & 0.711 & $0.268-1.882$ & 0.47 & 0.49096 \\
\hline & & $\mathrm{AT}+\mathrm{TT}$ & $63(0.77)$ & $44(0.83)$ & 0.678 & $0.28 I-1.638$ & 0.75 & 0.38640 \\
\hline & & A & $71(0.43)$ & $42(0.40)$ & Ref & & & \\
\hline & & $\mathrm{T}$ & $93(0.57)$ & $64(0.60)$ & 0.860 & $0.523-1.413$ & 0.36 & 0.55054 \\
\hline & rs3804099 & & $n=81$ & $n=55$ & OR & $95 \% \mathrm{Cl}$ & $\chi^{2}$-value & $P$-value \\
\hline & & $\mathrm{CC}$ & $22(0.27)$ & $18(0.33)$ & Ref & & & \\
\hline & & $\mathrm{CT}$ & $33(0.4 I)$ & $24(0.44)$ & 1.125 & $0.498-2.542$ & 0.08 & 0.77699 \\
\hline & & $\mathrm{TT}$ & $26(0.32)$ & $13(0.23)$ & 1.636 & $0.658-4.072$ & 1.13 & 0.28835 \\
\hline & & $\mathrm{CT}+\mathrm{TT}$ & $59(0.73)$ & $37(0.67)$ & 1.305 & $0.619-2.752$ & 0.49 & 0.48440 \\
\hline & & $\mathrm{C}$ & $77(0.48)$ & $60(0.55)$ & Ref & & & \\
\hline & & $\mathrm{T}$ & $85(0.52)$ & $50(0.45)$ & 1.325 & $0.815-2.153$ & 1.29 & 0.25614 \\
\hline
\end{tabular}

Abbreviations: SNP, single-nucleotide polymorphism; TLR2, Toll-like receptor 2; BC, breast cancer; OR, odds ratio; Cl, confidence interval; Ref, reference. 
Table 6 Comparison of genotype frequencies of SNPs in the TLR2 gene between ER +ve Saudi BC cases and healthy controls

\begin{tabular}{|c|c|c|c|c|c|c|c|c|}
\hline Gene & SNP ID & Genotype & Breast, n (\%) & Controls, n (\%) & OR & $95 \% \mathrm{Cl}$ & $\chi^{2}$-value & $P$-value \\
\hline \multirow[t]{21}{*}{ TLR2 } & rs3804I00 & & $n=75$ & $n=146$ & & & & \\
\hline & & $\mathrm{CC}$ & $\mathrm{I}(0.0 \mathrm{I})$ & $4(0.03)$ & Ref & & & \\
\hline & & $\mathrm{CT}$ & $15(0.2)$ & $27(0.18)$ & 3.000 & $0.303-29.663$ & 0.95 & 0.32911 \\
\hline & & TT & $59(0.79)$ & II5 (0.79) & 2.682 & $0.292-24.593$ & 0.82 & 0.36500 \\
\hline & & $\mathrm{CT}+\mathrm{TT}$ & $74(0.99)$ & I42 (0.97) & $2.74 I$ & $0.300-25.013$ & 0.86 & 0.35244 \\
\hline & & C & $17(0.11)$ & $35(0.12)$ & Ref & & & \\
\hline & & $\mathrm{T}$ & $133(0.89)$ & $257(0.88)$ & 1.118 & $0.588-2.123$ & 0.12 & 0.73393 \\
\hline & rs4696480 & & $n=75$ & $n=138$ & OR & $95 \% \mathrm{Cl}$ & $\chi^{2}$-value & $P$-value \\
\hline & & AA & $16(0.21)$ & $25(0.18)$ & Ref & & & \\
\hline & & AT & $34(0.45)$ & $63(0.46)$ & 0.930 & $0.424-2.038$ & 0.03 & 0.85552 \\
\hline & & $\mathrm{TT}$ & $25(0.34)$ & $50(0.36)$ & 0.800 & $0.353-1.815$ & 0.28 & 0.59361 \\
\hline & & $\mathrm{AT}+\mathrm{TT}$ & $59(0.79)$ & $113(0.82)$ & 0.870 & $0.420-1.804$ & 0.14 & 0.70813 \\
\hline & & A & $66(0.44)$ & $1 \mathrm{I} 3(0.4 \mathrm{I})$ & Ref & & & \\
\hline & & $\mathrm{T}$ & $84(0.56)$ & $163(0.59)$ & 0.881 & $0.579-|.34|$ & 0.35 & 0.55444 \\
\hline & rs3804099 & & $n=75$ & $n=146$ & OR & $95 \% \mathrm{Cl}$ & $\chi^{2}$-value & $P$-value \\
\hline & & $\mathrm{CC}$ & $21(0.28)$ & $42(0.29)$ & Ref & & & \\
\hline & & $\mathrm{CT}$ & $36(0.48)$ & 71 (0.49) & 1.121 & $0.562-2.235$ & 0.11 & 0.74589 \\
\hline & & TT & $18(0.24)$ & $33(0.22)$ & 1.121 & $0.498-2.521$ & 0.08 & 0.78258 \\
\hline & & $\mathrm{CT}+\mathrm{TT}$ & $54(0.72)$ & $104(0.7 I)$ & 1.121 & $0.588-2.137$ & 0.12 & 0.72880 \\
\hline & & C & $78(0.52)$ & $155(0.53)$ & Ref & & & \\
\hline & & $\mathrm{T}$ & $72(0.48)$ & I 37 (0.47) & 1.065 & $0.704-1.612$ & 0.09 & 0.76539 \\
\hline
\end{tabular}

Abbreviations: SNP, single-nucleotide polymorphism; TLR2, Toll-like receptor 2; ER, estrogen receptor; BC, breast cancer; OR, odds ratio; Cl, confidence interval; Ref, reference.

linked to different infectious diseases. ${ }^{27}$ The present study investigated whether polymorphisms of TLR2 are associated with the development of BC among women in the Kingdom of Saudi Arabia, to enable identification of markers for diagnosis and treatment. The choice of these SNPs was based on the fact that TLR2 rs4696480 is located in the promoter region and may affect the regulation of TLR2 transcription. Two other SNPs, rs3804099 and rs3804100, are located in the exonic region of the TLR2 gene (Table S1). Polymorphisms in coding regions play a fundamental role in the regulation

Table 7 Comparison of genotype frequencies of SNPs in the TLR2 gene between ER -ve Saudi BC cases and healthy controls

\begin{tabular}{|c|c|c|c|c|c|c|c|c|}
\hline Gene & SNP ID & Genotype & Breast, n (\%) & Controls, n (\%) & OR & $95 \% \mathrm{Cl}$ & $\chi^{2}$-value & $P$-value \\
\hline \multirow[t]{21}{*}{ TLR2 } & rs3804100 & & $n=47$ & $n=146$ & & & & \\
\hline & & $\mathrm{CC}$ & $0(0.00)$ & $4(0.03)$ & Ref & & & \\
\hline & & $\mathrm{CT}$ & $8(0.17)$ & $27(0.18)$ & 3.732 & $0.180-77.172$ & 1.52 & 0.21704 \\
\hline & & $\mathrm{TT}$ & $39(0.83)$ & II 5 (0.79) & 4.017 & $0.211-76.419$ & 1.75 & 0.18600 \\
\hline & & $\mathrm{CT}+\mathrm{TT}$ & $47(\mathrm{I})$ & I $42(0.97)$ & 0.18600 & $0.208-74.648$ & 1.72 & 0.18945 \\
\hline & & C & $8(0.09)$ & $35(0.12)$ & Ref & & & \\
\hline & & $\mathrm{T}$ & $86(0.91)$ & $257(0.88)$ & 1.536 & $0.673-3.506$ & 1.05 & 0.30558 \\
\hline & rs4696480 & & $n=49$ & $n=138$ & OR & $95 \% \mathrm{Cl}$ & $\chi^{2}$-value & $P$-value \\
\hline & & AA & $12(0.24)$ & $25(0.18)$ & Ref & & & \\
\hline & & AT & $16(0.33)$ & $63(0.46)$ & 0.583 & $0.235-1.445$ & 1.37 & 0.24194 \\
\hline & & TT & $21(0.43)$ & $50(0.36)$ & 0.896 & $0.37 \mid-2.167$ & 0.06 & 0.80804 \\
\hline & & $\mathrm{AT}+\mathrm{TT}$ & $37(0.76)$ & $1 \mathrm{I} 3(0.82)$ & 0.728 & $0.325-1.629$ & 0.60 & 0.43828 \\
\hline & & A & $40(0.4 I)$ & $113(0.4 \mathrm{I})$ & Ref & & & \\
\hline & & $\mathrm{T}$ & $58(0.59)$ & $163(0.59)$ & 1.004 & $0.619-1.629$ & 0.00 & 0.98760 \\
\hline & rs3804099 & & $n=48$ & $n=146$ & OR & $95 \% \mathrm{Cl}$ & $\chi^{2}$-value & $P$-value \\
\hline & & $\mathrm{CC}$ & $9(0.19)$ & $42(0.29)$ & Ref & & & \\
\hline & & $\mathrm{CT}$ & $22(0.46)$ & 7I (0.49) & 1.598 & $0.658-3.884$ & 1.08 & $0.2984 I$ \\
\hline & & $\mathrm{TT}$ & $17(0.35)$ & $33(0.22)$ & 2.470 & $0.950-6.424$ & 3.53 & 0.06033 \\
\hline & & $\mathrm{CT}+\mathrm{TT}$ & $39(0.81)$ & $104(0.71)$ & 1.889 & $0.824-4.328$ & 2.30 & 0.12909 \\
\hline & & C & $40(0.42)$ & I55 (0.53) & Ref & & & \\
\hline & & $\mathrm{T}$ & $56(0.58)$ & $137(0.47)$ & 1.615 & $0.996-2.619$ & 3.81 & 0.05096 \\
\hline
\end{tabular}

Abbreviations: SNP, single-nucleotide polymorphism; TLR2, Toll-like receptor 2; ER, estrogen receptor; BC, breast cancer; OR, odds ratio; Cl, confidence interval; Ref, reference. 
of TLR2 gene expression. Consequently, SNPs may affect TLR2 expression and activity by changing the transcription factor binding and mRNA stability. ${ }^{28}$ Several recent studies have examined the relationship between TLR polymorphisms and cancer, ${ }^{29}$ and one study revealed that tumorigenesis can inhibit TLR activation. ${ }^{19,30-32}$ The inhibition of TLR activation results in immunosuppression owing to chronic inflammation, and this would likely lead to cancer development. ${ }^{33}$ Although the role of TLRs in cancer has been documented, relatively few studies have examined the association between TLR2 polymorphisms and BC development. The results of the current investigation on the TLR2 rs3804100, rs4696480, and rs3804099 polymorphisms indicate that they are not associated with BC in a Saudi population. Contrary to the current results, research conducted in our laboratory has indicated an association between polymorphisms of TLR 2 and colon cancer development in the same ethnic group (in press). This discordance of data may be attributed to specificities of the polymorphism. Indeed, theses SNPs could make a specific marker for colon cancer, but not for BC diagnosis. In addition, the relationship between TLR2 polymorphisms and BC might be strongly apparent in other SNPs not examined here. A previous study reported a positive association between the TLR2 -196 to -174 del polymorphism and an increased risk of BC in a Greek population. ${ }^{34}$ Similarly, a linkage between genotypic variations in TLR2 and protection against, or susceptibility to, inflammatory disease is evident in other ethnic groups. TLR2 rs3804099 and rs3804100 have been closely connected with hepatocellular carcinoma (HCC), ${ }^{27}$ gastric cancer, ${ }^{35}$ and PTC in Korean patients. ${ }^{21}$ However, no study has evaluated the role of these TLR2 polymorphisms in $\mathrm{BC}$ risk. To date, no functional data on these TLR2 polymorphisms are available. Because of the location of TLR2 rs4696480 in the regulatory region of the gene, it is possible that the function, but not expression, of the TLR2 gene is affected in this polymorphism.

In this study, we showed a significant correlation ( $P$-value $=0.05)$ between the rs3804099 polymorphism located in an exon of TLR2 and ER -ve BC susceptibility in $\mathrm{BC}$ patients compared to healthy ER - ve controls. This low $P$-value might be because of the limited number of $\mathrm{BC}$ patients within this subgroup compared with controls. Therefore, we suggest increasing the number of BC samples in future studies.

\section{Conclusion}

Results from our study indicate no association between the TLR2 polymorphisms tested and susceptibility to BC in a Saudi female population. However, we suggest studying other
TLR2 SNPs to investigate the possible association between innate immunity deregulation by disruption of TLR2 and BC. Further investigation is required to demonstrate whether TLR2 deregulation may also occur in other ethnic populations.

\section{Disclosure}

The authors report no conflicts of interest in this work.

\section{References}

1. Siegel RL, Miller KD, Jemal A. Cancer statistics, 2016. CA Cancer J Clin. 2016;66(1):7-30.

2. Najjar H, Easson A. Age at diagnosis of breast cancer in Arab nations. Int J Surg. 2010;8(6):448-452.

3. Akira S, Takeda K, Kaisho T. Toll-like receptors: critical proteins linking innate and acquired immunity. Nat Immunol. 2001;2(8):675-680.

4. Karin M, Lawrence T, Nizet V. Innate immunity gone awry: linking microbial infections to chronic inflammation and cancer. Cell. 2006;124(4):823-835.

5. Bhatelia K, Singh K, Singh R. TLRs: linking inflammation and breast cancer. Cell Signal. 2014;26(11):2350-2357.

6. Takeda K, Akira S. Toll-like receptors in innate immunity. Int Immunol. 2005;17(1):1-14.

7. Wang JQ, Jeelall YS, Ferguson LL, Horikawa K. Toll-like receptors and cancer: MYD88 mutation and inflammation. Front Immunol. 2014; 5:367.

8. Huang B, Zhao J, Unkeless JC, Feng ZH, Xiong H. TLR signaling by tumor and immune cells: a double-edged sword. Oncogene. 2008;27(2):218-224.

9. Niedzielska I, Niedzielski Z, Tkacz M, et al. Toll-like receptors and the tendency of normal mucous membrane to transform to polyp or colorectal cancer. J Physiol Pharmacol. 2009;60(suppl 1):65-71.

10. Simiantonaki N, Kurzik-Dumke U, Karyofylli G, Jayasinghe C, MichelSchmidt R, Kirkpatrick CJ. Reduced expression of TLR4 is associated with the metastatic status of human colorectal cancer. Int J Mol Med. 2007;20(1):21-29.

11. Bhide MR, Mucha R, Mikula I Jr, et al. Novel mutations in TLR genes cause hyporesponsiveness to Mycobacterium avium subsp. paratuberculosis infection. BMC Genet. 2009;10:21.

12. Kutikhin AG. Association of polymorphisms in TLR genes and in genes of the toll-like receptor signaling pathway with cancer risk. Hum Immunol. 2011;72(11):1095-1116.

13. Kutikhin AG, Yuzhalin AE. Inherited variation in pattern recognition receptors and cancer: dangerous liaisons? Cancer Manag Res. 2012;4: $31-38$.

14. Semlali A, Reddy Parine N, Arafah M, et al. Expression and polymorphism of toll-like receptor 4 and effect on NF-kappaB mediated inflammation in colon cancer patients. PLoS One. 2016;11(1):e0146333.

15. Stevens VL, Hsing AW, Talbot JT, et al. Genetic variation in the tolllike receptor gene cluster (TLR10-TLR1-TLR6) and prostate cancer risk. Int J Cancer. 2008;123(11):2644-2650.

16. de Oliveira JG, Silva AE. Polymorphisms of the TLR2 and TLR4 genes are associated with risk of gastric cancer in a Brazilian population. World J Gastroenterol. 2012;18(11):1235-1242.

17. Milne AN, Carneiro F, O'Morain C, Offerhaus GJ. Nature meets nurture: molecular genetics of gastric cancer. Hum Genet. 2009;126(5): 615-628.

18. Mandal RK, George GP, Mittal RD. Association of toll-like receptor (TLR) 2, 3 and 9 genes polymorphism with prostate cancer risk in North Indian population. Mol Biol Rep. 2012;39(7):7263-7269.

19. Killeen SD, Wang JH, Andrews EJ, Redmond HP. Exploitation of the toll-like receptor system in cancer: a doubled-edged sword? Br J Cancer. 2006;95(3):247-252.

20. Slattery ML, Herrick JS, Bondurant KL, Wolff RK. Toll-like receptor genes and their association with colon and rectal cancer development and prognosis. Int J Cancer. 2012;130(12):2974-2980. 
21. Kim MK, Park SW, Kim SK, et al. Association of toll-like receptor 2 polymorphisms with papillary thyroid cancer and clinicopathologic features in a Korean population. J Korean Med Sci. 2012;27(11): 1333-1338.

22. Wang XQ, Liu L, Liu Y, Zhang K. TLR-2 gene polymorphisms and susceptibility to cancer: evidence from meta-analysis. Genet Test Mol Biomarkers. 2013;17(12):864-872.

23. Alanazi M, Pathan AA, Abduljaleel Z, et al. Association between PARP-1 V762A polymorphism and breast cancer susceptibility in Saudi population. PLoS One. 2013;8(12):e85541.

24. Lavole A, Toper C, Belmont L, Ruppert AM, Wislez M, Cadranel J. [Lung cancer and HIV infection]. Rev Mal Respir. 2014;31(2):133-141.

25. Akira S, Takeda K. Toll-like receptor signalling. Nat Rev Immunol. 2004; 4(7):499-511.

26. Liew FY, Xu D, Brint EK, O'Neill LA. Negative regulation of toll-like receptor-mediated immune responses. Nat Rev Immunol. 2005;5(6): 446-458.

27. Junjie X, Songyao J, Minmin S, et al. The association between tolllike receptor 2 single-nucleotide polymorphisms and hepatocellular carcinoma susceptibility. BMC Cancer. 2012;12:57.

28. Thomas KH, Meyn P, Suttorp N. Single nucleotide polymorphism in $5^{\prime}$-flanking region reduces transcription of surfactant protein B gene in H441 cells. Am J Physiol Lung Cell Mol Physiol. 2006; 291(3):L386-L390.
29. Zhou H, Hickford JG, Fang Q, Lin YS. Allelic variation of the ovine toll-like receptor 4 gene. Dev Comp Immunol. 2007;31(2):105-108.

30. Koido S, Homma S, Okamoto M, et al. Improved immunogenicity of fusions between ethanol-treated cancer cells and dendritic cells exposed to dual TLR stimulation. Oncoimmunology. 2013;2(8):e25375.

31. Okamoto M, Sato M. Toll-like receptor signaling in anti-cancer immunity. J Med Invest. 2003;50(1-2):9-24.

32. Sato S, Sugiyama M, Yamamoto M, et al. Toll/IL-1 receptor domaincontaining adaptor inducing IFN-beta (TRIF) associates with TNF receptor-associated factor 6 and TANK-binding kinase 1, and activates two distinct transcription factors, NF-kappa B and IFNregulatory factor-3, in the toll-like receptor signaling. J Immunol. 2003; 171(8):4304-4310.

33. Andrade CF, Kaneda H, Der S, et al. Toll-like receptor and cytokine gene expression in the early phase of human lung transplantation. $J$ Heart Lung Transplant. 2006;25(11):1317-1323.

34. Theodoropoulos GE, Saridakis V, Karantanos T, et al. Toll-like receptors gene polymorphisms may confer increased susceptibility to breast cancer development. Breast. 2012;21(4):534-538.

35. Zeng HM, Pan KF, Zhang Y, et al. [The correlation between polymorphisms of toll-like receptor 2 and toll-like receptor 9 and susceptibility to gastric cancer]. Zhonghua Yu Fang Yi Xue Za Zhi. 2011;45(7): 588-592. 


\section{Supplementary material}

Table SI Characteristics of selected polymorphisms in the TLR2

\begin{tabular}{llll}
\hline SNP ID & $\begin{array}{l}\text { Chromosome } \\
\text { position }\end{array}$ & $\begin{array}{l}\text { Nucleotide } \\
\text { change }\end{array}$ & Region \\
\hline $\begin{array}{l}\text { rs3804100 } \\
\text { Ser450Ser }\end{array}$ & $4 / 153704257$ & $+1350 \mathrm{C}>\mathrm{T}$ & Exon \\
rs4696480 & $4 / 153685974$ & $-16934 \mathrm{~T}>\mathrm{A}$ & Promoter \\
rs3804099 & $4 / 153703504$ & $+597 T>C$ & Exon \\
\hline Asn199Asn & & & \\
\hline
\end{tabular}

Abbreviations: TLR2, Toll-like receptor 2; SNP, single-nucleotide polymorphism.

\section{Publish your work in this journal}

OncoTargets and Therapy is an international, peer-reviewed, open access journal focusing on the pathological basis of all cancers, potential targets for therapy and treatment protocols employed to improve the management of cancer patients. The journal also focuses on the impact of management programs and new therapeutic agents and protocols on

\section{Dovepress}

patient perspectives such as quality of life, adherence and satisfaction. The manuscript management system is completely online and includes a very quick and fair peer-review system, which is all easy to use. Visit http://www.dovepress.com/testimonials.php to read real quotes from published authors. 